\title{
FORMS AND SPECIFICS OF RESOURCE PROVISION OF ECONOMIC SUBJECTS IN AGRICULTURE
}

\begin{abstract}
The article contains a description and an analysis of the forms and details of economic resources of agriculture, determined the specificity of the strategy of resources provision in terms of development and operation. As the authors study the terms of technical reequipment and modernization of the agricultural technology, we could tell that the production of major agricultural products, which require a high level of intensification of production should be concentrated in relatively large formations of different legal forms: societies and associations of various types, co-operatives. However, the role of households as forms of self-employment is still very important and needs to be the subject of state support, since concentration and specialization in agriculture will lead to the unification of crops and lack of variety of food products for market. As it could be seen from figure presented in the article, all labor-intensive products are produced in the households, with the small exception of milk production, due to its unprofitability. As we studied forms and specifics of resource provision of economic subjects in agrarian sphere, we could make the conclusion, that issues of ownership heavily distorted the resource provision of agricultural enterprises, making them hosts for household active economic activity, which make no good for future of agriculture sector in a whole and to the resource saving in particular. Such symbiosis has helped for the rural people to survive, but in the long perspective put off Ukrainian agriculture development. Summarizing all said before, we can say that the strategies of specialization and concentration are not always sufficient tool for the development of agriculture in rural areas, because it does not fully take into account the range of production, especially with the high cost of labor.
\end{abstract}

Keywords: households, farms, agriculture, property, resources, agricultural production

\section{INTRODUCTION TO THE PROBLEM}

The formation of market relations in the agricultural sector is based on finding optimal forms of management and on the diversity of ownership. However, in many ways, formality of agrarian reform has become an obstacle to achieve effective results. The success of the reform, according to its initiators, is largely dependent on the foundation and functioning of individualized ownership that can lead to the formation of a critical mass of rural producers, able to manage effectively in a market environment to meet the needs of our society in agricultural production and ensure our country food security. But twenty-two years of work in a given direction gave more problems than solutions, so there

\footnotetext{
${ }^{1}$ Andrzej Gerasymchuk, dr.hab, professor of philosophy department of Zhytomir State University named after I. Franko.

${ }^{2}$ Nataliia Gerasymchuk, PhD, Associate Professor of Department of Economics of Enterprises, National University of Life and Environmental Sciences of Ukraine, Heroyiv Oborony st., 15, Kyiv - 03041, Ukraine, corresponding author: 90999nag@mail.ru
} 
is a need to analyze the resource availability of a basic level of economic principles of production.

The problems of resource provision of economic subjects in agriculture had been analyzed in the works of many well-known Ukrainian scientists such as Andriichuk V.G., Geets V.M., Gorovyi V.P., Zaburanna L.V., Zinovchuk V.V., Il'chuk M.M., Malik M.I. , Tereshchenko V.K., Tkachuk V.A., Shtymak I.V. Yurchishin V.V. and many others. Despite rather detailed analysis of the problem, the current state of agricultural sector in the context of sustainable development throws new challenges to be addressed, one of the most pressing is the issue of resource saving. But before finding the solution to any problem, the first step is to analyze and collect data on the situation, the action this article is dedicated to.

The aim of this article is to study the forms and the specific of resource provision of economic subjects of agriculture in the light of economic theory and philosophy of capital forming on the small agricultural enterprise.

\section{ANALYSIS OF THE FORMS AND FEATURES OF ECONOMIC RESOURCES OF AGRICULTURE}

Reorganization of agricultural enterprises has not created conditions for the emergence of effective owner in the Ukrainian village. This process was complicated by compromise and inconsistent character of agrarian legislation, as well as social conflicts within households. Until now, Ukrainian legislation does not provide a legal norm of private ownership of agricultural land and the possibility of their sale. More than $80 \%$ of agricultural land in the course of privatization were transferred from state ownership into ownership groups - common ownership of farms workers and retired people from collective farms. Out of $\sim 12000$ collective farms were created, 7 million new small landowners and only 57000 farm structures. In addition to a rigid legislation, land relations were even more limited by articles of newly created and reorganized enterprises - joint stock companies, partnerships and cooperatives. They are usually recorded only the right to share in the capital and renting it and otherwise restrict the possibility of allocating a portion from the share, followed by its withdrawal from the agriculture enterprise land. Even greater difficulties were associated with the sharing out of the property. So really, in most cases the land and property could be sold only within the coowners of former collective farm. All these constraints have led to the fact that the number of employees who have benefited from the right to withdraw their shares of land and property with the aim of creating a farm, was extremely small.

The presence of many small owners of farms has led to a paradoxical, from the standpoint of Tereshchenko V.K. ${ }^{3}$, situation: lack of ownership in the classical sense. So today economic subjects in agriculture may be more adequately described in terms of three groups of interests within the agricultural enterprise, rather than owners.

1 Group: Personnel of agricultural enterprise. Small wages and irregular payments does not allow employees to consider labor as the main source of income. Therefore, they are interested in getting resources by preserving old symbiotic relationship, and their personal garden plots, up to parasitism on it. Symbiotic relationship of households and agricultural enterprises is a key point of the pseudo effectiveness of private farming,

\footnotetext{
${ }^{3}$ Socio-economic development of villages and rural areas [Text] / P.A. Laiko, V.K. Tereshchenko, A.G. Borsch [and others] - K.: Nichlava, 2006. - p. 24
} 
which during the significant decline in production on agricultural enterprises have increased their contribution to the agricultural production in the country with $31 \%$ in 1991 to $54 \%$ in 2012 and produce $96.7 \%$ of potato, $77 \%$ of milk, $98 \%$ of honey having only $36 \%$ of the land. (Table 1$)^{4}$

2 group: nominal owners (retired workers and social workers of the village). Their economic interest is to receive dividends (rents) for their land and property shares. Today, the size of these payments are negligible, and therefore, a low level of pensions and wages in rural areas for this group the main source of income also remains garden plots ${ }^{5}$ Consequently, they are also interested in getting (both by legal and illegal means) natural resources from agricultural enterprises.

Table 1.Total land area and distribution of agricultural land between landowners and land users in 2012 (at end of year; thousands hectares)

\begin{tabular}{|c|c|c|c|c|c|}
\hline & \multirow{2}{*}{$\begin{array}{l}\text { Total land } \\
\text { area }\end{array}$} & \multirow{2}{*}{$\begin{array}{l}\text { Total } \\
\text { agricultural land }\end{array}$} & \multicolumn{3}{|c|}{ Of which } \\
\hline & & & $\begin{array}{l}\text { arable } \\
\text { land }\end{array}$ & hayfields & pastures \\
\hline Total land area & 60354,8 & 41576,0 & 32476,5 & 2410,9 & 5481,9 \\
\hline $\begin{array}{l}\text { Land of agricultural } \\
\text { enterprises and individuals }\end{array}$ & 37843,8 & 36487,9 & 30932,1 & 1604,8 & 2972,2 \\
\hline including : & & & & & \\
\hline \begin{tabular}{|c} 
land of agricultural \\
enterprises
\end{tabular} & 21376,5 & 20589,6 & 19237,4 & 410,2 & 729,3 \\
\hline of which state & 1205,8 & 1022,0 & 844,9 & 33,5 & 107,3 \\
\hline non-state & 20170,7 & 19567,6 & 18392,5 & 376,7 & 622,0 \\
\hline land of individuals & 16467,3 & 15898,3 & 11694,7 & 1194,6 & 2242,9 \\
\hline Land of other land users & 22511,0 & 5088,1 & 1544,4 & 806,1 & 2509,7 \\
\hline
\end{tabular}

3 Group: Manager of the agricultural enterprise, who although has almost unlimited access to the resources sector, is a hired manager, elected by the general meeting of owners. He may be re-elected at any time, and hence, also motivated to maximize the benefits "here and now". In the absence of real property management where is no mechanism of blocking of rent-oriented behavior of the director and his desire for private gain from taking of inefficient economic decisions.

There is a classic "free rider effect": the manager can take advantage of his position, while costs of ineffective actions are shifted on all owners as a whole, or to the State (local authorities), which are forced to subsidize unprofitable agricultural enterprises.

The distribution of agricultural property in Ukraine today refers to the symbolic nature of the rights owners, the imbalance of economic power and the regime of open access to

\footnotetext{
${ }^{4}$ Statistical Bulletin "Agriculture - 2012" - Kyiv, Statistical Committee of Ukraine, 2013. - p. 79

${ }^{5}$ Basics of agricultural enterprise [Text] / M. I. Malik, P.T.Sabluk, V.V.Zinovchuk [et al.] - : Institute of Agricultural Economics , 2000. - p. 581
} 
agricultural resources. Such property relations do not motivate any of the groups of owners of farms to achieve efficiency in the long term, but rather provoke them to extract rents at the expense of enterprise' assets. This increases production and transaction costs in the form of the theft and inefficient decisions. Restructured collective farms in their current form is characterized by opportunistic form of behavior based on the possibility of reducing of contribution of the collective owners to agricultural enterprises produced product without a corresponding decrease in their individual income. This causes underestimation of individual costs of inefficient behavior of economic agents and overestimate of their costs of efficient operation. This leads to excess use of resources of the enterprise and, therefore, its low productivity and unprofitability. Loss-making enterprise cannot provide their employees and shareholders a decent income, so those who should be interested to drag him out of it, takes everything out of the enterprise. Institutional trap closes ${ }^{6}$.

Similar view has Staritskaya O.P., noting that the reform of property relations in agriculture does not solve the problem of effective owner of agricultural sphere. The large number of collective farms smallholders who cannot really influence the management of enterprises that do not receive income from the property led to a lack of interest in the efficiency of farms in the long term, illegal redistribution of resources from collective enterprises in households ${ }^{7}$.

The transformation of the institutional system of the agrarian sector, according to Rogach S.M., had led to the dominance of households, as they became the owners of the various factors of production and the expense of their resources they start to provide the necessary level of income and protect themselves from the adverse effects of the environment ${ }^{8}$. She shares the position of those authors who are differentiate two types of households: the traditional and entrepreneurial. An integral part of the traditional household are garden plots and country-vegetable farms, which are used primarily to fulfill their own needs. The main purpose of the household is the survival (sometimes it's just a hobby). Distinction of household of entrepreneurial orientation is orientation to achieve a success with the priority of market values. To this type we may include classic family farms. Production in the farms of this type is done through the use of entrepreneurial skills of household members in the system of production factors.

There is no doubt that in a stable economy, ensuring a certain level of income received in the public sector, households are functioning as a source of self- provision. But precisely in times of crisis and decline in living standards of the rural population selfsustaining function of private farming transformed by a sharp rise in their level of marketability.

In practice, foreign statistics and the relevant recommendations of the international statistical agencies, including global standards, the term "private farming" is not used. Activity of the population with employment in the households is seen as a part of

\footnotetext{
${ }^{6}$ Socio-economic development of villages and rural areas [Text] / P.A. Laiko, V.K. Tereshchenko, A.G. Borsch [and others] - K.: Nichlava, 2006. - p. 163

${ }^{7}$ Staritskaya O.P Resources in the economic mechanism of improving the efficiency of agricultural production / / Scientific notes of TDPU after. V. Hnatiuk. Series: Economics. - 2005 . - № 18. - p. 200 .

${ }^{8}$ Rogach S.M. Institutional aspects of land reform in agriculture : // The productive forces of Ukraine . - 2010. - № 2-4. - p.114
} 
the informal (unorganized) activity. The revised UN System of National Accounts (Chapter 4 Institutional units and sectors) is separating economic activity in the formal and informal in households subsector. The informal sector is regarded as a group of production units, which in accordance with the definitions and classification of United National System of National Accounts forms part of the household sector as household enterprises.

Household production, as the informal sector, according to Shtimak Igor ${ }^{9}$, is characterized by the following features: self-financing of production activities; autonomy and legal capacity; inseparability of the household from its members; lack of registration in the prescribed form in accordance with existing legislation; labor relations based on family or personal relationships, and sometimes based on irregular employment.

Variety of sectors and activities that are developed in the household sector includes the production of market goods and services and non-market goods and services, including goods for their own use (final consumption and savings). This fact, according to Shtimak Igor, is a major methodological approach to understanding the essence of the concept of "households". Market household enterprises are created with the purpose of producing goods and services for sale and exchange. Non-market household enterprises are created in order to produce for their own use. Non-market household enterprises may sell part of production that exceeds their own needs, but if they are regularly engaged in selling most of their products, they should be considered as small businesses.

In the Law "On the households" \# 742-IV from 15.05.2003 emphasized that private farming is not a business. There is some analogy of private farming with the nonprofit organization. Latter does not have profit as its primary objective, but it is not forbidden for them to engage in entrepreneurial activities, provided spending the proceeds from these activities for the authorized purposes of the organization. Thus, a non-profit organization, even engaging in entrepreneurial activity does not become commercial. The same can be said about households: production of marketable products in it even in large volumes does not make private farming into a variety of business, because the income is not used for commercial purposes, but for private (family) consumption. But, undoubtedly, a significant proportion of households may well be attributed to small businesses, not from a tax perspective, but in terms of the inner nature of activities.

At the beginning of market reforms big hopes were put for family and large farms as the most successful form of implementation of private property in the agricultural sector. During time of reforming of agricultural sector households playing key role in providing food for the country and are the main factor of additional income of rural population, which is shown by statistical data (Figure 1$)^{10}$

\footnotetext{
${ }^{9}$ Shtymak I. Socio-economic conditions of households : monograph. - Kyiv, NUBiP, 2011. - p. 153

${ }^{10}$ Statistical Bulletin "Agriculture - 2012" - Kyiv, Statistical Committee of Ukraine, 2013. - p. 147
} 


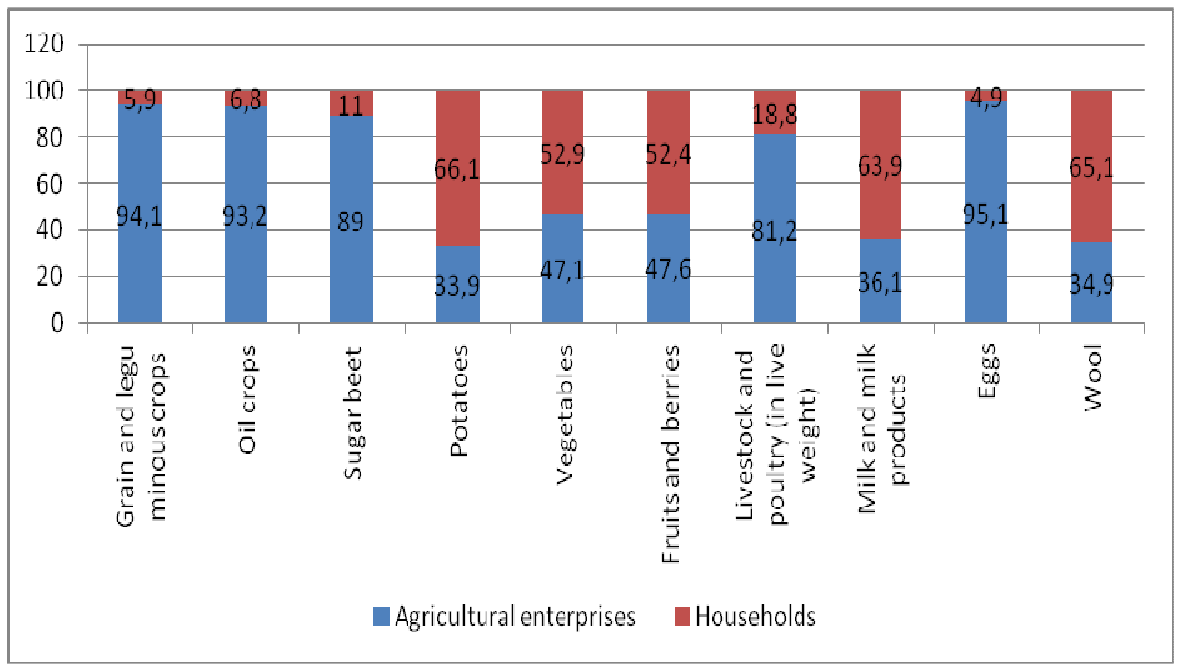

Figure 1. Structure of sale of main kinds of agricultural production by types of agricultural holdings in 2012, \%

Household, in one form or another, will prove its competitiveness and opportunities for sustainable development in a variety of economic conditions.

The issue of socio-economic entity of individual farm in the form of peasant was the object of study of many prominent economists. But if Smith and Ricardo were classifying peasant as a small bourgeoisie, Marx considered its content deeper. As the owner of the means of production, he is a capitalist, as an employee - its own employee. Thus, as a capitalist, he pays himself wages and derives its income from its capital, ie exploits himself as wage laborer in the form of surplus value that pays tribute to himself that the work has to give to the capital. As well as the landlord peasant pays himself more than third of rent ${ }^{11}$.

Being in the same time the worker, the bourgeoisie and the landlord, the peasant did not fit into the classical network of politically-economic categories. The economic essence of peasant differs sharply from the spirit of a large agrarian bourgeoisie as agriculture is here mainly for the sake of survival ${ }^{12}$. Absolute boundary for the peasant, according to Marx, as for the small capitalist is only wage, which he actually pays himself. While the price of the product covers salary for him, he will cultivate his land - often up until it covered only by physical minimum wage ${ }^{13}$. On the other hand, independent peasant categorically rejects psychology of employee. To compete in the food market peasant must implement a variety of functions directly related to the process of production and sale of products and services. In other words, peasant is performing different economic activity independently - a producer who becomes merchant and capitalist ${ }^{14}$. Such an interpretation of a peasant is especially applied to modern conditions to determine essence of household concept.

\footnotetext{
${ }^{11}$ Karl Marx. Capital. The Process of Capitalist Production as a Whole - Vol. 2nd ed.- T.25 . - p. 57

${ }^{12}$ Ibid - p.371

${ }^{13}$ Ibid. - p. 370

${ }^{14}$ Ibid. - p. 367
} 
Goriovyi V.P. ${ }^{15}$ emphasizes that farmer enterprise, as a legal form of business activity, bears the intrinsic characteristics which objectively determines its strengths. A number of advantages arises with the size of the enterprise. These include: a combination in one person of the owner and manager willingness to take business risks, the opportunity to participate in programs to support small businesses, the ability to use fixes agricultural tax.

\section{JUSTIFICATION OF DEVELOPMENT OF THE AGRICULTURAL RESOURCES STRATEGY IN UKRAINE}

Assessment of the potential and prospects of the development of farming forms of business allows us to conclude that they are directly determined by the size of the entity and its level of resource security. Smallholders with low provision of essential resources with respect to the effective functioning associated with the development of industries that traditionally require significant manual labor. In the sector of labor-intensive products (vegetables, potatoes, berries, flowers, etc.) farmers on small plots of land can compete and to find its niche in the market. Another way to increase the sustainability of their development is the cooperation between the farmers, with agricultural enterprises and households. For medium-sized farms increasing of production efficiency is related to the optimization of its structure and approach to optimal resource proportions providing increasing returns all resources used. For large farms with a high degree of concentration of capital opportunities to build their resource potential defined a whole set of factors, which, along with the optimization of the combination of rural industries should allocate cash flow optimization, processing facilities, the complex of services, etc.

But no individual subsidiary or peasant (farmer's) economy cannot be the basis of large-scale production, based on the use of high technology and capital and to improve the efficiency of resource use at the enterprise level due to the concentration of production arising in the development process of cooperation and integration.

Theoretically, it is proved that the concentration of the process within the enterprise is advisable to conduct until the effect of growth of scale will be a positive value. The effect of scale refers to the effect of reducing the cost per unit of output in the allocation of fixed costs to the growing volume of production, which perfectly fits in the main task of resource saving activity. Economies of scale driven by factors that reduce the long-term average production costs, as company increases the amount of used resources and products.

Marginal utility theory objectively proves that the increase of some resources at a constant value of others leads to a drop in the efficiency of these inputs up to a situation where costs are aimed at increasing the scale of production may exceed the resulting economic benefits. That is, the concentration of production in its economic essence is a way to achieve optimal resource proportions within the socio-economic systems of different levels.

Limitations of systems (especially at the microeconomic level) objectively leads to a situation where in the process of concentration of production will be a deficiency of a particular resource, which could not be overcame due to absence of internal reserves. In this case, the positive effect of scale can be achieved only with the consolidation of assets

\footnotetext{
${ }^{15}$ Goriovyi V.P. Problems of rational combinantion of small, medium and large enterprises //Agroinkom . - 2007. - № 11-12. - p. 74-78 .
} 
of several agricultural enterprises. Typically, the process of consolidation of assets realized through the development of cooperation and integration processes, and in some cases, through the acquisition of one of the production structure on the other.

Indeed, if at the beginning of ideologists of radical reforms relied on small-scale production (it was told about "farmerizing" of Ukraine), then in the late nineties of the XX century Ukrainian government began to support on the development of cooperation and agroindustrial integration in order to attract investment in the agricultural sector, which will be able to restore the productive capacity of the agricultural sector.

Realities of today show that only large farms due to the concentration of capital can use all factors of production and the latest technology to achieve maximum effect. For example, in the United States over the past 50 years the number of farms decreased three times. Farms themselves have become much larger and more developed largely due to government support. In Europe there is a different system. Farms are grouping together in cooperatives, which are shareholders of large processing plants. ${ }^{16}$

Investigation of the structure of the agrarian sector economic subjects of Ukraine leads to the conclusion that the most important factors determining the specificity of the formation of the production systems of various types of business are ownership and forms of management. World experience shows that the efficiency of the agrarian policy of any state is determined primarily by its ability to provide a concentration of ownership in the hands of economic subjects whose competence must be determined not only by their "economic power", but also the ability to effectively implement the functions of agricultural production based on sustainable development of rural areas.

Economic theory has shown that the most effective use of resources can be achieved at the highest possible scale production. The desire to get the additional effect of the concentration of production explains the constant development of integration processes in agriculture. Integrated agro-industrial formation based on complete fusion of property objectively can more freely operate with labor and material resources. An additional effect of the concentration of production is achieved with the integration of business entities with heterogeneous capital structure and with a sufficiently high arrhythmia consumption of working capital, but interconnected in the functioning of the system of stable economic relations. Process control functions ensure that all resource units in integrated formation, tend to concentrate in the integrator enterprise. Decisions on the distribution of production in the context of business units and the allocation of appropriate levels of resources are taken at new quality level.

Agricultural companies of different legal forms scale of production, as a rule, allows the formation of a potentially efficient production enterprise by balancing and achieving optimal resource proportions. The choice of the best combination of resources are based on the financial capacity of organizations and quality analysis of economic conditions on a given planning horizon. It should be noted that the size of companies allows optimal level of utilization of all types of agricultural machinery (including high technological), cost-effective form of working capital, developed warehouses and other production infrastructure.

Households are deprived of these opportunities, using labor of family members. In them effective management of limited amount of resources is determined primarily by

\footnotetext{
${ }^{16}$ Zinovchuk V.V. The cooperative idea in agriculture of Ukraine and the United States [Textbook ] - Second edition, ext. and revised. - K. : Logos , 1996. - p. 124
} 
entrepreneurial abilities of its leader. Most farmers, experiencing a significant decline of fixed and current assets, forced to abandon the use of modern technology, which allow to save these resources. Development potential of the farm business is directly determined by the size of farms and their level of resource security. For households with low-resource prospects associated with the development of industries that traditionally require significant manual labor, and the possibilities of co-operation among themselves or with agricultural organizations. Of farms for midsize growth in production efficiency associated with the optimization of their resource proportions and deepening specialization. For households with a sufficiently high level of resource supply priority for more efficient use of resources will be the concentration of capital and production.

Particularly noteworthy is the problem of resource maintenance of households activities. The phenomenon of production efficiency in private farms began to crumble as soon as a process of elimination or absorption of agricultural organizations that were centers for rural settlements. It turned out that without the support of resource providing agricultural enterprises householders could not allow to keep production on the same level. Furthermore, in terms of job cuts in the rural areas was a natural "washout" of active business people from agricultural production. So the main resource of households manual labor - proved to be just as deficient.

\section{CONCLUSIONS}

Summarizing of all said before, we can say that in terms of technical re-equipment and modernization of the agricultural component of its technology, the production of major agricultural products, requiring a high level of intensification of production will be concentrated in relatively large formations of different legal forms: societies and associations of various types, co-operatives. However, the role of households as forms of self-employment is still very important and needs to be subject of state support, since concentration and specialization in agriculture will lead to the unification of crops and lack of variety of food products for market. As could be seen from figure 1, all laborintensive products are produced in the households, with the small exception of milk production, due to its unprofitability. As we studied forms and specifics of resource provision of economic subjects in agrarian sphere, we could make the conclusion, that issues of ownership heavily distorted the resource provision of agricultural enterprises, making them hosts for household active economic activity, which make no good for future of agriculture sector in a whole and to the resource saving in particular. Such symbiosis have helped for the rural people to survive, but in the long perspective put off Ukrainian agriculture development.

\section{LITERATURE:}

[1] Andriychuk V.G. Economics of agricultural enterprises. -K. : KNEU , 2013.

[2] Goriovyi V.P. Problems of rational combinantion of small, medium and large enterprises //Agroinkom . - 2007. - № 11-12.

[3] Socio-economic development of villages and rural areas [Text] / P.A. Laiko, V.K. Tereshchenko, A.G. Borsch [and others] - K.: Nichlava, 2006.

[4] Zinovchuk V.V. The cooperative idea in agriculture of Ukraine and the United States [Textbook ] - Second edition, ext. and revised. - K. : Logos , 1996.

[5] Karl Marx. Capital. The Process of Capitalist Production as a Whole - Vol. 2nd ed.- T.25 . 
[6] Basics of agricultural enterprise [Text] / M. I. Malik, P.T.Sabluk , V.V.Zinovchuk [et al.] - : Institute of Agricultural Economics , 2000.

[7] Rogach S.M. Institutional aspects of land reform in agriculture : // The productive forces of Ukraine . - 2010. - № 2-4.

[8] Staritskaya O.P Resources in the economic mechanism of improving the efficiency of agricultural production / / Scientific notes of TDPU after. V. Hnatiuk. Series: Economics. - 2005 . - № 18.

[9] Statistical Bulletin "Agriculture - 2012" - Kyiv, Statistical Committee of Ukraine, 2013.

[10] Shtymak I. Socio-economic conditions of households : monograph. - Kyiv, NUBiP, 2011.

\section{KSZTAET I CECHY ŚWIADCZENIA ZASOBÓW PRZEDSIĘBIORSTW ROLNYCH}

Tekst zawiera opis i analizę form i szczegółów zasobów gospodarczych rolnictwa, określono specyfikę strategii ubezpieczenia zasobów z punktu rozwoju i działania. W wyniku szczegółowej analizy podstawowych zasad teorii ekonomicznej i historii tworzenia zasobów określono podstawy rozwoju gospodarki rolnej Ukrainy. Autorzy zbadali warunki dla zapewnienia modernizacji techniki i maszyn rolniczych i doszli do wniosku, że produkcja podstawowych produktów rolnych, które wymagają wysokiego poziomu intensyfikacji produkcji powinna być skoncentrowana w stosunkowo dużych formacjach o różnych formach prawnych: stowarzyszeń i zrzeszeń różnych typów spółdzielni. Niemniej jednak jest rola gospodarstwa domowego jako formy samozatrudnienia. Gospodarstwa domowe są bardzo ważne i powinny być przedmiotem pomocy państwa, ponieważ koncentracja i specjalizacja rolnictwa prowadzi do unifikacji kultur i brak wyboru produktów spożywczych na rynku. Jak widać z rysunku przedstawionego w artykule, wszystkie produkty pracochłonne są wytwarzane w gospodarstwach domowym, z kilkoma wyjątkami, w postaci mleka, ze względu na jego niską rentowność. Autorzy badali formy i możliwości ubezpieczenia zasobów gospodarczych w sektorze rolnym i stwierdzili, że kwestia własności w dostarczanie zasobów w dużym stopniu ma wpływ na przedsiębiorstwa rolne poprzez ich rolę jako donorów dla działalności gospodarczej gospodarstw domowych, co ma negatywny wpływ w ogóle na przyszłość sektora rolnictwa, a w szczególności oszczędzania zasobów. Ta symbioza pomogła mieszkańcom na wsi przetrwać, ale w dłuższej perspektywie spowolniła rozwój ukraińskiego rolnictwa. Podsumowując, można powiedzieć, że strategie koncentracji i specjalizowania nie zawsze są dostatecznym narzędziem rozwoju rolnictwa na obszarach wiejskich, gdyż nie w pełni uwzględniają asortyment produkcji, zwłaszcza z wysokimi kosztami robocizny.

Słowa kluczowe: gospodarstwa domowe, gospodarstwa rolnicze, zasoby, produkcja rolna.

DOI:10.7862/rz.2014.hss.18

Przesłano do redakcji: maj 2014

Przyjęto do druku: lipiec 2014 